\title{
Phenotypic factors and genetic group on the selling price formation of beef calves sold in auctions at the Northern region of Paraná State, Brazil
}

\author{
Fatores fenotípicos e grupo genético na formação do preço final de bezerros de corte \\ comercializados em leilões na região norte do Estado do Paraná, Brasil

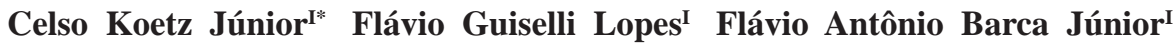 \\ Luis Afonso Marques Claus ${ }^{\mathrm{II}}$ Maria Eugênia Andrighetto Canozzi ${ }^{\mathrm{II}}$ \\ Silvio Renato Oliveira Menegassi ${ }^{\mathrm{II}}$ Matheus Dhein Dill ${ }^{\mathrm{IV}}$ Júlio Otávio Jardim Barcellos ${ }^{\mathrm{III}}$
}

ABSTRACT

The aim of this study is to estimate the effects of phenotypic traits on the final price of calves sold at auctions in the region of northern Paraná. Data were collected between April 2011 and April 2012 at 12 auctions, in which 197 lots were offered, totaling 4,289 animals. In this study, only the final prices charged when the deals were closed have been considered. Calves belonging to the British genetic group reached higher marketing value than zebu calves; the largest animals presented higher liquidity; buyers preferred more uniform lots, regardless of the sex of the animals.

Key words: calves auction, commercialization, cow-calf production, frame size, marketing.

RESUMO

Objetivou-se estimar os efeitos das características fenotípicas de bezerros, que podem influenciar no preço final, comercializados em leilões na região Norte do Paraná. Os dados foram coletados entre abril de 2011 e abril de 2012, em 12 leilões, em que foram ofertados 197 lotes, totalizando 4.289 animais, sendo os preços finais considerados somente nos casos de efetiva comercialização. Foi observado que os bezerros do grupo genético britânicos obtiveram valor de comercialização superior aos zebuínos; os animais de maior porte obtiveram maior liquidez; e, independente do gênero, os lotes com maior uniformidade tiveram preferência do consumidor.

Palavras-chave: leilão de bezerros, comercialização, rebanho de cria, tamanho, marketing.

\section{INTRODUCTION}

The effectiveness of beef cattle production is significantly influenced by the breeding stage, which involves reproduction (IEL/CNA/SEBRAE, 2000). This activity is considered to have the least profitability, the highest risk and minimum flexibility, although it is the basis for the subsequent stages of the process. Therefore, any inversion applied to it resulting in increased efficiency may benefit the whole beef cattle production cycle (EUCLIDES FILHO \& EUCLIDES, 2010).

Given the importance of these production systems, purchasing and selling animals have become fundamental stages, and it is important to avoid losses resulting from ineffective marketing, as they can be so significant that the activity may become unviable (AZEVEDO, 2009). The establishment of prices, besides being related to the rule of supply and demand as well as to production costs, is influenced by consumer behavior at the moment of negotiation, as a reflection of qualitative and quantitative characteristics of the animals being sold (CHRISTOFARI et al., 2008).

Several studies have shown that a number of factors affect the price of animals along the marketing process, such as physical, genetic and nutritional characteristics, and handling and market conditions (SULLIVAN \& LINTON, 1981; SCHROEDER et al., 1988; SARTWELLE et al., 1996; TROXEL \& BARHAM, 2007; LEUPP et al., 2008; CHRISTOFARI et al., 2009; CHRISTOFARI et al., 2010; SCHULZ et al., 2010). Therefore,

\footnotetext{
IFaculdade de Veterinária, Universidade Norte do Paraná (UNOPAR). Rodovia PR 218, Km 01, Jardim Universitário, 86702-670, Arapongas, PR, Brasil. E-mail: celsokoetzjr@yahoo.com.br.*Autor para correspondência.

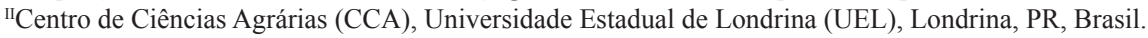

IIIDepartamento de Zootecnia, Universidade Federal do Rio Grande do Sul (UFRGS), Porto Alegre, RS, Brasil.

${ }^{\text {IV }}$ Centro de Estudos e Pesquisas em Agronegócios, UFRGS, Porto Alegre, RS, Brasil. Received 04.16.13 Approved 10.14.13 Returned by the author 01.30.14 CR-2013-0535.R3
} 
specialized breeding and marketing of animals with the characteristics required by buyers are strategies that can increase both the production and the productivity of a herd (TURNER et al., 1992; KASSIE et al., 2010), thus making the activity more profitable (CLEERE \& BOLEMAN, 2000).

In southern Brazil, producers usually have two options for marketing their beef calves: directly to other producers, or through auctions, at which buyers compete for the desired lot by bidding (CHRISTOFARI et al., 2006). However, in the north of Paraná, information about the factors affecting the price to be paid for the animals is scarce. Hence, this study aims at analyzing the influence of certain physical characteristics of calves, such as sex, genetic group, uniformity and frame size, on the price of the animals sold at auctions in that region.

\section{MATERIAL AND METHODS}

The study comprised the collection of data on 4,289 calves distributed in 197 lots which were marketed at 12 auctions in the northern region of Paraná from April 2011 to April 2012. A group of technical researchers was trained to assess and classify the lots by means of visual inspections at two moments: before the animals were shown at the auction, and during their stay in the sale ring.

Visual evaluation was performed at the local padlocks prior to the animals entrance into the sale ring, the lots were classified according to their genetic group, biotype, uniformity, sex and presence ( $\geq 5 \%$ of animals in relationship to the lot size) or absence $(<5 \%$ of animals in relationship to the lot size) of poor quality animals. Later, during the auction, information about the initial and final prices of the lots, time of permanence in the ring, profitability and price variation over time (months) was compiled. The average selling price of all animals were obtained in Brazilian currency (Reais; R\$) and transform to US dollars using a ratio of 1 US $\$=1.70 \mathrm{R} \$$, during the time period of the study, from April 2011 to April 2012.

In order to determine the genetic group, the lots were classified into two groups: lots containing 50 percent or more of taurine breeds, and lots totally composed of Nellore calves. Lots with calves whose breed or cross-breeding were unknown and dairy calves were excluded from the evaluation.

To characterize the prevailing biotype of each lot assessed, frame size and muscling were considered; scores ranging from 1 to 3 were established for frame size and muscling. Lots with prevalence of large animals with heavy muscling scored 1; lots composed of medium-sized animals with moderate muscling were assigned score 2; and lots in which small, light-muscled animals prevailed scored 3 (adapted from SEVERO, 1994).

For the purpose of uniformity assessment, the genetic group, frame size and muscling were considered; according to their appearance characteristics individually or combined in animals, the lots were then classified as uniform or nonuniform. For this reason, lots were classified as nonuniform when showed more than $5 \%$ of animals with one or more one poor characteristics (e.g.: gentic group and/or frame size and/or muscling), and as uniform when showed less than $5 \%$ of these conditions. The presence of only one calf with the signs described above, in lots with less than 20 animals, were classified as a non-uniform lot.

Poor quality animals were regarded as those that mischaracterized the group in terms of size, muscling or body conditions. All visual evaluations were performed in padlocks before animals entrance in the sale ring, independently of the lot size, all the calves were subjected to walk forward to identify any animal abnormal appearance, thus, to make sure all animals were evaluated.

All the information was tabulated in Microsoft Excel ${ }^{\circledR}$ spreadsheets and analyzed with the use of BIOESTAT 5.0 software package. For data presentation, the descriptive analysis was performed, including frequencies, means and standard deviations. After the examination of data normality, they were subjected to variance analysis (ANOVA), with a minimum significance level of 5 percent.

\section{RESULTS AND DISCUSSION}

The exploratory data analysis enabled us to find out that calf buyers are influenced by the characteristics of the animals. That was the reason why some calves are not sold (23.86 percent), and the liquidity percentage of the lots is 76.14 .

The prices of male calves sold were statistically higher than the prices paid for females (Table 1), a finding that is in accordance with results reported by MENKHAUS \& KEARL (1976). Studies carried out at North-American auctions in the region of Kansas and Arkansas (USA) identified higher prices of male calves in comparison to prices of bulls and heifers (SMITH et al., 2000; TROXEL \& BARHAM, 2007). Besides that, a larger supply of males $(65 \times 35 \%)$ was observed, which may be justified by the need of keeping part of the heifers for replacements. 
Table 1 - Average price per animal sold and relative frequency of lots at auctions in the Northern Region of Paraná from April 2011 to April 2012, according to the variables considered.

\begin{tabular}{|c|c|c|c|c|}
\hline Effect & Number of lots & Relative frequency (\%) & Average price/animal ${ }^{*}$ (US\$) & Tukey's test $^{* *}$ \\
\hline \multicolumn{5}{|l|}{ Year } \\
\hline $2011 / 1$ & 74 & 37.56 & $497.8 \pm 63.5$ & a \\
\hline $2011 / 2$ & 57 & 28.94 & $484.5 \pm 71.6$ & $\mathrm{a}$ \\
\hline $2012 / 1$ & 66 & 33.50 & $507.0 \pm 98.2$ & $\mathrm{a}$ \\
\hline \multicolumn{5}{|l|}{ Sex } \\
\hline M & 128 & 64.97 & $516.6 \pm 69.0$ & $\mathrm{~b}$ \\
\hline $\mathrm{F}$ & 69 & 35.03 & $457.0 \pm 83.0$ & $\mathrm{a}$ \\
\hline \multicolumn{5}{|l|}{ Genetic group } \\
\hline Cross-bred & 102 & 51.77 & $510.2 \pm 83.8$ & $\mathrm{a}$ \\
\hline Nellore & 95 & 48.23 & $482.3 \pm 71.7$ & $\mathrm{~b}$ \\
\hline \multicolumn{5}{|l|}{ Uniformity } \\
\hline Uniform & 92 & 46.70 & $524.0 \pm 77.6$ & $\mathrm{a}$ \\
\hline Non-uniform & 105 & 53.30 & $465.3 \pm 68.8$ & $\mathrm{~b}$ \\
\hline \multicolumn{5}{|c|}{ Poor quality animals } \\
\hline$<5 \%$ & 157 & 79.70 & $509.3 \pm 77.4$ & $\mathrm{a}$ \\
\hline$>5 \%$ & 40 & 20.30 & $434.5 \pm 54.5$ & $\mathrm{~b}$ \\
\hline \multicolumn{5}{|l|}{ Biotype } \\
\hline Small & 20 & 10.15 & $444.6 \pm 93.4$ & $\mathrm{~b}$ \\
\hline Medium & 124 & 62.94 & $483.6 \pm 67.0$ & $\mathrm{~b}$ \\
\hline Large & 53 & 26.91 & $542.6 \pm 78.8$ & A \\
\hline
\end{tabular}

${ }^{*}$ Values of average price/animal considered only the lots that were actually sold.

${ }^{* *}$ Different letters within the column differ $(\mathrm{P}<0.05)$ by Tukey's test.

In this study, buyers were willing to pay on average 11.54 percent more for males in comparison to females, since male calves were more suitable for their needs. This value was close to a standard deviation above the general mean of valorization of the products marketed $(7.45 \pm 5.56)$.

As to the genetic group, $48.23 \%$ of the animals marketed were zebu, while $51.77 \%$ were preponderantly taurine cross-breeds. A significant difference $(\mathrm{P}<0.05)$ was seen in the average prices of these genetic groups, with a higher valorization of cross-bred animals (5.46\%) probably due to heterosis. This result is in agreement with findings by CHRISTOFARI et al. (2008), who reported that higher prices and valorization were reached by synthetic breeds (Brangus, Braford and Canchim) at auctions held in Rio Grande do Sul. From the analysis of data related to 10 years of television auctions in Arkansas (SA), TURNER et al. (1992) also found that selling prices were affected by breed. However, TROXEL \& BARHAM (2007) claimed that neither specific breed nor a breed type was marketed for higher prices, and that Angus x Brahman, Angus x Hereford and Angus were the most valued animals.

The evaluation of the uniformity of the lots enabled us to summarize all the analyzed physical characteristics in one single criterion. Overall, the mean and standard deviation for the uniform and non-uniform lots were $22.29 \pm 8.83$ and $21.50 \pm 9.07$, respectively. The average frequency were 1.0 and 2.0 for uniform and non-uniform lots, respectively.

A significant difference $(\mathrm{P}<0.05)$ between uniform and mixed lots was found; the average value of uniform lots was US\$ 524.0 \pm 77.6 . Preference for uniform lots at North-American auctions was also reported by SMITH et al. (2000) and SCHULZ et al. (2010). CHRISTOFARI et al. (2009) explained that such preference for uniform lots has a strong impact on the purchase decision in periods of large supply of calves; however, when the supply is relatively low, the price difference between lots is small, regardless the uniformity of the lots. 
Concerning the relationship between the presence of poor quality animals and the value of lots, it was possible to notice that lots with less than 5 percent of poor quality animals were more valued, with an average selling price of US $\$ 509.3 \pm 77.4$ while those with more than 5 percent of this kind of animals reached an average price of US\$ $434.5 \pm 54.5$; these values are statistically different $(\mathrm{P}<0.05)$. More homogeneous lots represented $79.7 \%$ of the sales, thus evidencing a better knowledge of this aspect by calf sellers. Interesting, from the remaining lots (20.3\%), we observed that $12(6.09 \%)$ had less than 20 animals, suggesting the presence of animals without parameters to be commercialized. The overall mean and standard deviation for these groups were $23.70 \pm 9.54$ and $12.58 \pm 3.48$, respectively.

For SARTWELLE et al. (1996), physical characteristics are determinant of cattle prices. Among them, frame size is an important characteristic. In this study, there was a statistic difference $(\mathrm{P}<0.05)$ for male frame size. Lots classified as large were more valorized in comparison to the ones with medium and small-sized animals, which did not statistically differ. TROXEL \& BARHAM (2007), working with data collected from 2000 to 2005 in Arkansas (USA), as well as SCHULZ et al. (2010), considering information gathered in the 2008-2009 period in Kansas and Missouri (USA), found that smallframed calves were not wanted, hence, they were devalued. SCHROEDER et al. (1988) concluded that large, muscled animals are preferred because they can be either used for breeding or destined for finishing.

However, as table 1 shows, $73.09 \%$ of the supply consisted of medium and small-sized animals. This may have been due to the following reasons: sellers' unawareness of the kind of animals with the most demand; shortage of larger animals in the market; or retention of bigger animals at breeding and fattening farms. Such results are similar to those found by CHRISTOFARI et al. (2008). According to the authors, the larger supply of medium-sized animals is related to a characteristic that is typical of production systems in Rio Grande do Sul, where the breeding activity is concentrated in marginal areas. This causes producers to raise medium-sized cows, as they have lower maintenance requirements (BARCELLOS et al., 2000).

As to prices, their stability became evident. This tendency was also seen in the analysis performed by the Center of Advanced Studies in Applied Economics (CEPEA - ESALQ/USP). The study showed that the prices of calves were US\$ 467.0 and 438.22 in the states of Mato Grosso and São Paulo, respectively, in the same period considered in this investigation. Prices found in the northern region of Paraná were higher than in those states probably because the analysis conducted by used prices collected at the farms of origin as a basis of estimate, while in this study the prices were recorded at specialized auctions that incorporate other costs into the minimum selling price, such as commissions and transportation fees.

From observation of 110 lots, it was possible to notice that the average marketing time was 3 minutes in the ring. Half of the lots were sold along the third minute in the ring at an average price of US\$ 489.0 \pm 73.8 , which does not statistically differ ( $\mathrm{P}>0.05$ ) from other marketing times; other lots were not sold, indicating that buyers can rapidly identify the products that interest them (Table 2).

\section{CONCLUSION}

It was possible to conclude that the price of calves marketed at the auctions analyzed was stable from 2011 to 2012. Uniform lots composed of larger

Table 2 - Distribution of lots at auctions in the Northern Region of Paraná from April 2011 to April 2012, according to time in the ring and average sales price.

\begin{tabular}{|c|c|c|c|c|}
\hline Time in the ring & Number of lots & Relative frequency (\%) & Average price/animal (US\$) & Tukey's test" \\
\hline 1 minute & 1 & 0.91 & $476.5 \pm 0.0$ & A \\
\hline 2 minutes & 19 & 17.27 & $458.6 \pm 72.8$ & A \\
\hline 3 minutes & 56 & 50.91 & $489.0 \pm 73.8$ & A \\
\hline 4 minutes & 17 & 15.45 & $536.0 \pm 89.2$ & A \\
\hline 5 minutes & 12 & 10.91 & $575.7 \pm 54.2$ & A \\
\hline 6 minutes & 4 & 3.64 & $535.3 \pm 28.1$ & A \\
\hline 7 minutes & 1 & 0.91 & $591.2 \pm 0.0$ & A \\
\hline Total & 110 & 100 & & \\
\hline
\end{tabular}

${ }^{*}$ Different letters within the column differ $(\mathrm{P}<0.05)$ by Tukey's test. 
taurine cross-bred male calves, with a lower number of poor quality animals, were more valued. Such information could be used by all the segments of the production chain as a knowledge source that could cause a closer approximation between producers and buyers of beef calves.

\section{REFERENCES}

AZEVEDO, P.F.Comercialização de produtos agroindustriais. In: BATALHA, M.O. Gestão agroindustrial. São Paulo: Atlas, 2009.p.63-112.

BARCELLOS, J.O.J. et al. Ganadería de cría en ambientes subtropicales: sub-trópico argentino y centro-sur brasileño. Revista Argentina de Producción Animal,sn, p.1-13, 2000.

CHRISTOFARI, L.F. et al.Mercado de terneiros: é possível a obtenção de melhores preços alterando as características do produto. In:JORNADA TÉCNICA EM SISTEMAS DE PRODUÇÃO DE BOVINOS DE CORTE E CADEIA PRODUTIVA: tecnologia, gestão e mercado, 2006, Porto Alegre, RS, Brasil. Proceedings... Porto Alegre: NESPRO/UFRGS, 2006.(CD-ROM).

CHRISTOFARI, L.F.et al.Tendências na comercialização de bezerros relacionadas às características genéticas no Rio do Sul. Revista Brasileira de Zootecnia, v.37, n.1, p.171-176, 2008 Available from: <http://www.scielo.br/scielo.php?pid=S1516$35982008000100025 \&$ script $=$ sci arttext $>$. Accessed: Nov. 12, 2012. doi: 10.1590/S1516-35982008000100025.

CHRISTOFARI, L.F.et al.Manejo da comercialização em leilões e seu efeito no preço de bezerros de corte. Revista Brasileira de Zootecnia, v.38, n.1, p.196-203, 2009. Available from: <http://www.scielo.br/scielo.php?pid=S151635982009000100024\&script $=$ sci_arttext $>$. Accessed: Oct. 25, 2012. doi: 10.1590/S1516-35982009000100024.

CHRISTOFARI, L.F.et al. Efeitos do peso vivo sobre a comercialização de bezerros de corte em leilões. Arquivo Brasileiro de Medicina Veterinária e Zootecnia,v.62, n.2, p.419-428, 2010. Available from: $<$ http://www.scielo.br/scielo.php?script=sci artte xt\&pid=S0102-09352010000200023 . Accessed: Oct. 25, 2012. doi: $10.1590 /$ S0102-09352010000200023.

CLEERE, J.J.; BOLEMAN, L.L.Production and marketing high value calves. College Station, TX: Texas Cooperative Extension, The Texas A\&M University System, 2000.6p.(Extension publicationn. E-409).

EUCLIDES FILHO, K.; EUCLIDES, V.P.B. Desenvolvimento recente da pecuária de corte brasileira e suas perspectivas. In:PIRES,A.V. Bovinocultura de corte. Piracicaba: FEALQ, 2010.p.11-40.

IEL/CNA/SEBRAE. Estudo sobre a eficiência econômica e competitividade da cadeia agroindustrial da pecuária de corte no Brasil. Brasília, 2000. 285p.
KASSIE, G.T. et al.Implicit prices of Indigenous bulls traits in crop-livestock mixed production systems of Ethiopia. African Development Review, v.22, n.4, p.482-494, 2010. Available from: $<$ http://onlinelibrary.wiley.com/doi/10.1111/j.14678268.2010.00244.x/pdf>. Accessed: Sept. 23, 2012. doi: 10.1111/j.1467-8268.2010.00244.x.

LEUPP, J.L.et al. Factors influencing price of North Dakota, South Dakota and Montana feeder calves. In: WEST SECTION OF AMERICAN SOCIETY OF ANIMAL SCIENCE, 59., 2008, Laramie, USA. Proceedings... Laramie: ASAS, 2008. n.32.

MENKHAUS, D.J.; KEARL, W.G. Influence of breed, sex, lot size and weight. Journal of Animal Science, v.42, n.6, p.1389-1396, 1976. Available from: <http://www.journalofanimalscience.org/ content/42/6/1389.full.pdf $>$. Accessed: Dec. 05, 2012.

SARTWELLE, J.D.III et al. Improving the value of your calf crop: the impact of selected characteristics on feeder cattle prices. Manhattan, KS: Cooperative Extension Service, Kansas State University, 1996.14p. (Report n. MF-2142).

SCHROEDER, T. et al. Factors affecting feeder cattle price differentials. Western Journal of Agricultural Economics, v.13, n.1, p.71-81, 1988.Available from: <http://ageconsearch.umn.edu/ bitstream/32161/1/13010071.pdf $>$. Accessed: Sept. 12, 2012.

SCHULZ, L. Factors affecting feeder cattle prices in Kansas and Missouri. Manhattan, KS: K-State Department of Agricultural Economics, Kansas State University, 2010. 12p.

SEVERO, J.L.P. Manejo e controle de produção para a implantação de um programa de melhoramento genético de bovinos de corte. Bovinos de corte: seleção e cruzamento. Porto Alegre: GenSys Consultores Associados, 1994. 80p.

SMITH, S.C. Effect of selected characteristics on the sale price of feeder cattle in eastern Oklahoma. Stillwater, OK: Oklahoma Cooperative Extension Service, Division of Agricultural Science and Natural Resources, Oklahoma State University, 2000. 14p. (Report n. E - 955).

SULLIVAN, G.M.; LINTON, D.A.Economic evaluation of an alternative marketing system for feeder cattle in Alabama. Southern Journal of Agricultural Economics, v.13, n.2, p.85-89, 1981. Available from: <http://ageconsearch.umn.edu/ bitstream/30125/1/13020085.pdf >. Accessed: Nov. 22, 2012.

TROXEL, T.R.; BARHAM, B.L.Comparing the 2000 and 2005 factors affecting the selling price of feeder cattle sold at Arkansas livestock auctions. Journal of Animal Science, v.85, n.12, p.34253433, 2007.Available from: <http://www.journalofanimalscience. org/content/85/12/3425.full.pdf+html>. Accessed: Dec. 05, 2012. doi: $10.2527 /$ jas.2007-0339.

TURNER, S.C. et al.Market value and managerial decisions: implications from a decade of feeder cattle teleauctions. Journal of Animal Science, v.70, n.4, p.1015-1021, 1992.Available from: $<$ http://www.journalofanimalscience.org/content/70/4/1015>. Accessed: Dec. 13, 2012. 